\title{
湾奥部閉鎖性水域における貧酸素水塊の 消長への影響因子
}

\author{
FACTORS THAT INFLUENCE THE DEVELOPMENT AND DECLINE OF \\ ANOXIC WATER AT AN ENCLOSED WATER AREA IN THE HEAD OF A BAY
}

\author{
入江政安 $1 \cdot$ 西村和幸 $2 \cdot$ 佐々木昇平 $2 \cdot$ 西田修三 $3 \cdot$ 中辻啓二 4 \\ Masayasu IRIE, Kazuyuki NISHIMURA, Shohei SASAKI, Shuzo NISHIDA \\ and Keiji NAKATSUJI
}

\begin{abstract}
1正会員 博（工） 大阪大学大学院助手 工学研究科土木工学専攻（广565-0871 吹田市山田丘2-1）
2学生会員 大阪大学大学院 工学研究科土木工学専攻（T565-0871 吹田市山田丘2-1）

3 正会員 工博 大阪大学大学院助教授 工学研究科土木工学専攻（广565-0871 吹田市山田丘2-1)

4正会員 工博 大阪大学大学院教授 工学研究科土木工学専攻（广565-0871 吹田市山田丘2-1）
\end{abstract}

\begin{abstract}
Water near sea bottom in the head of a bay into which a lot of nutrients flow becomes deficient in oxygen during summer. The characteristics of the anoxic water are different between in the whole bay and at the enclosed area in the head of the bay. The vertical difference of temperature and DO (dissolved oxygen) in a bottom layer are correlative in the whole bay, and not so at the enclosed area. It is because there is excess consumption of oxygen at the enclosed area, which is influenced well on by the water temperature under a thermocline. In the present paper the factors which have influence on the development and decline of the anoxic water are discussed. When the anoxic water mass develops early in summer, the development of that depends on the temperature of the middle layer close under the thermocline. The higher temperature leads more consumption of oxygen in the process of the degradation of detritus. This consumption of oxygen is more important factor of the dynamics of anoxic water at the enclosed area than in the whole bay.
\end{abstract}

Key Words : anoxic water, dissolved oxygen, enclosed coastal waters, field survey, Osaka Bay

\section{1. はじめに}

湾奥部閉鎖性水域の水質悪化は，人工島や防波堤の造 成による海水交換の低下やそれに伴う成層構造の発達に 起因するところが大きい，大都市近傍の内湾では，底層 水の貧酸素化は珍しくないが, 湾奥部の閉鎖性水域にお いては，さらに貧酸素化が進み，港内のさらなる水質悪 化を招いている. このような水域では, 貧酸素化を防ぐ ことが重要である.しかし，湾奥部の閉鎖性水域でみら れる貧酸素水塊は, 湾全域で観測される貧酸素水塊と比 べて, その発生機構や発達・消隇過程が異なり, 未だ十 分に解明されていない.

尼崎西宮芦屋港を図-1に示す。図-2に2003年7月15日の 港内の底層DOの分布を示す. 以下, 本研究では, 溶存 酸素(DO)が3mg/以下である状態を貧酸素状態と呼ぶこ とにする，夏季の底層DOはほとんど $\mathrm{mg} /$ に近く, 無酸 素化している. 中辻ら(以下, 前々報と呼ぶ)では, 貧酸
素水塊は6月にはすでに発生しており, 夏季においては, 風況の変化などにより一時的に貧酸素水塊が縮小するこ とがあっても, 強固に存在し続けることを示した. 港奥 では, DO3mg/となる水深は水温躍層と一致しており, 植物プランクトンの生産が盛んな上層以外の, 貧酸素化 しうる領域全てが貧酸素化している．城汭は大阪湾全域 の底層のDOについて, 表底水温差 (=表層の水温一底 層の水温）との相関が大きいとしているが, 本対象領域 では，底層がほぼ0mg/の状況にあるので，このような 相関は得られにくい. そこで, 貧酸素水塊の発達状況の 一評価指標としての貧酸素水塊厚 (=全水深-DO3mg/ となる水深）と表底水温差の相関を調べたが，その相関 は大きくなかった．酸素消費に水温が影響するのは明ら かであるが，前々報では閉鎖性水域の貧酸素化における 水温の役割について十分に明らかにすることはできな かった.

入江ら ${ }^{3)}$ (以下前報と呼ぶ）では，貧酸素水塊の短期 


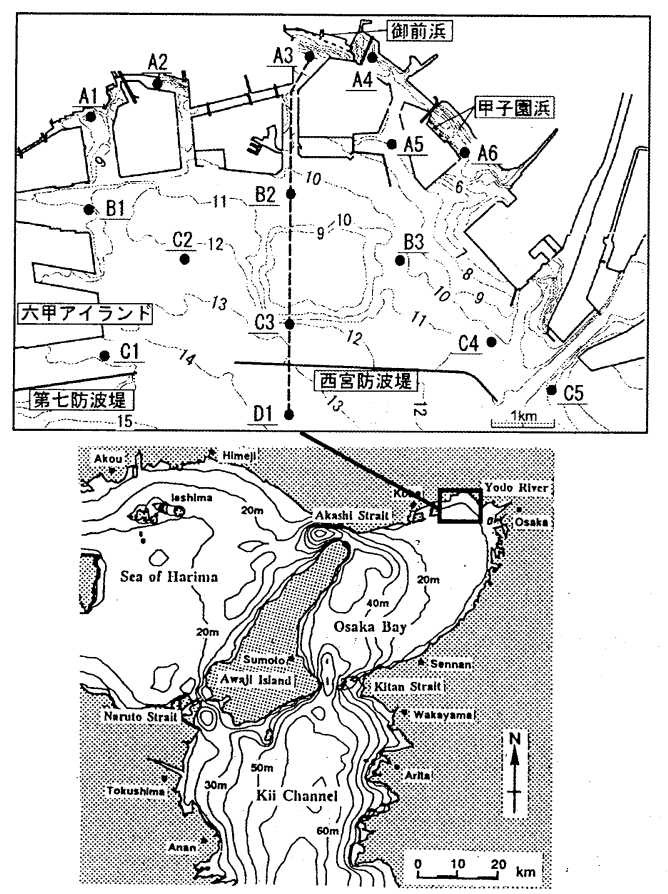

因-1 大阪湾と観測対象領域

的な挙動に及ぼす気象の影響について考察した. 港内の 貧酸素水塊は, 低気圧の通過などによる北寄りの風の連 吹によって，港奥で湧昇し，場合によっては青潮が発生 する. このとき, 港奥から港中央部にかけては表層近く まで貧酸素状態となっている. 城2)は，湾全体の貧酸素 水塊について, 北風が連吹した場合に貧酸素水塊が縮小 する傾向にあるとしているが，港内に限って言えば，貧 酸素水塊の拡大を助長していると見ることもできる.

以上のように, 大阪湾全体の貧酸素水塊と湾奥部閉鎖 性水域のそれでは，その発生機構や消長特性が異なると 考えることができ，更なる調査が必要とされた．そこで, 著者らは2003年においても2002年と同様の観測を行い, データの蓄積とより詳細な分析を行うこととした.

本研究では，閉鎖性水域の貧酸素水塊の機構解明に向 けて，2力年にわたる港湾域の詳細な貧酸素水塊調査結 果を基に, 貧酸素水塊の消長に関わる影響因子を明らか にすることを目的とする. 本報では2002年と2003年の観 測結果の比較から,

(1) 酸素消費の「主役」とそれに影響を及ぼす因子

(2) 港内のDOの消長へ及ぼす気象の変動の影響 を明らかにすることを目的として，主にDOと水温の季 節変動に着目した解析と考察を行う.

\section{2. 調査の概要}

\section{(1)対象領域の概要}

本研究の対象領域の尼崎西宮芦屋港は東西約 $6.7 \mathrm{~km}$, 南北約 $4.6 \mathrm{~km}$ である. 対象領域周縁の人工島には, 港湾 施設, マンション, 工場, 倉庫などが立地する. 港湾内

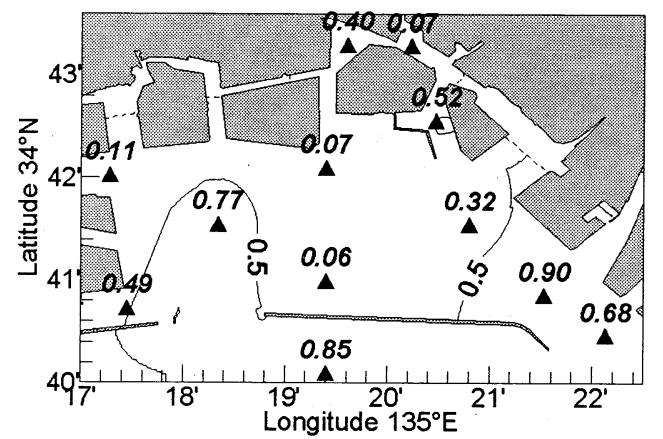

国-2 底層の $\mathrm{DO}(\mathrm{mg} / \mathrm{f})$ の水平分布(2003年7月15日)
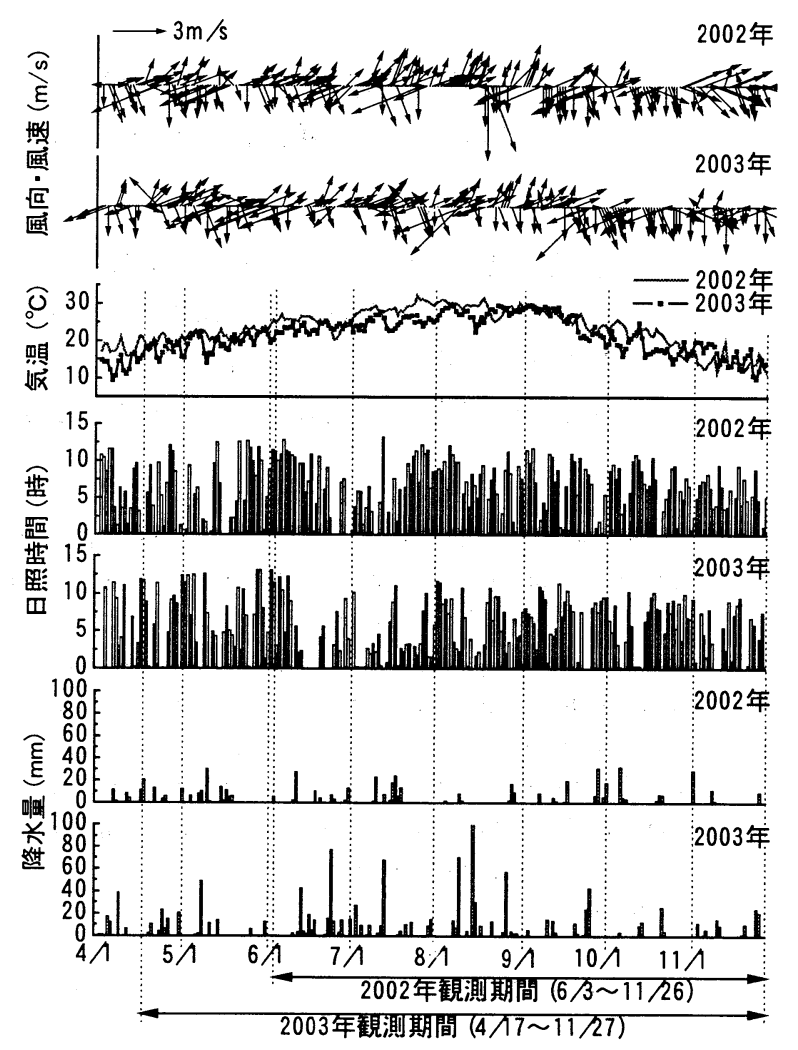

国-3 観測期間中の風向 - 風速, 気温, 日照時間, 降水量

には甲子園浜, 御前浜などの砂浜やマリンスポーツのた めの施設があり，大阪湾奥部のなかでも，住民が比較的 海岸線に近寄りやすい地域である．沖には，西宮防波堤 があり，この水域における水交換は，西側の神戸港と接 続する 2 つの水路 $($ 幅 $0.4 \mathrm{~km}, 0.7 \mathrm{~km}$ ), 南西側の神戸港第 7防波堤と西宮防波堤間の航路(幅1.6km), 東側の西宮防 波堤東端の開口部(幅1.3km)のみでなされており，閉鎖 性の強い水域となっている. 水深は5〜14mである. 淀 川の出水のあるときには, 東側開口部から淡水が侵入す る.

貧酸素水塊は夏季において，本対象領域を含む大阪湾 奥部で観測され，その範囲はおおむね水深 $20 \mathrm{~m} の$ 等深線 より東側である2).

\section{(2)調査の内容}

調査は，2002年には6月3日から11月26日，2003年には 

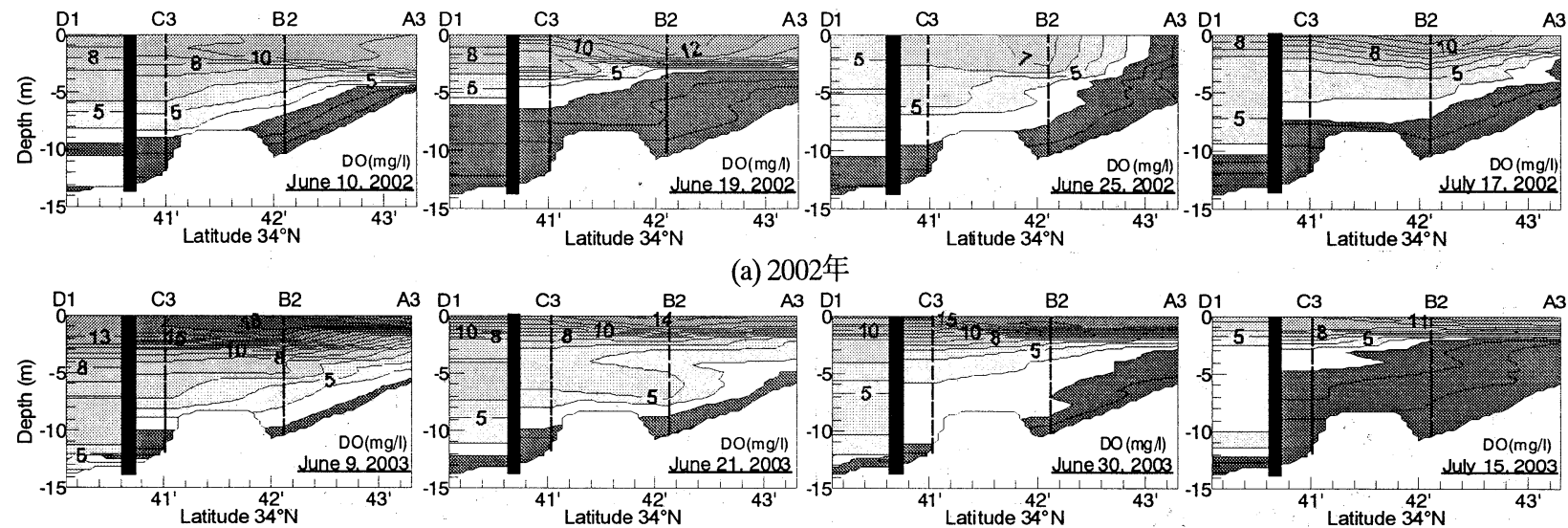

(b) 2003 年

国-4 DOの縦断分布の経時変化の比較

4月17日から11月26日にかけて実施した。調査項目はク ロロフィルセンサー付きSTD計（アレック電子製ACL220）による塩分, 水温, クロロフィルa, 濁度, および,

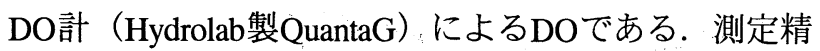
度向上のために, DOの計測においては各水深において 少なくとも1分以上の計測を実施した. 調査間隔は1〜2 週間に1回である. 調査地点数は15点で, 2003年の7月以 降は測点A1，A2，A6を除く12点で観測を実施した.

図-3に2002年と2003年の調查期間中の神戸海洋気象台 で観測された風向・風速および気温，降水量，日照時間 を示す．2002年と2003年の6月の月平均気温はそれぞれ

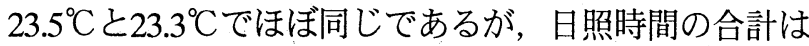
200.4時間と127.8時間，降水量の合計は $75 \mathrm{~mm}$ と216mmで あった. 2002年の6月は平年に比べて，雨の少ない安定 した気候であった．一方で，両年の11月の平均気温はそ れぞれ $11.0^{\circ} \mathrm{C}$ と $15.9^{\circ} \mathrm{C} て ゙ ， 2002$ 年の秋季は平年に比べて， 気温が低かった。

\section{3. 分酸素水塊の発達・衰退に及ぼす影響因子}

本章では貧酸素水塊の季節変動を発達期, 最盛期, 衰 退期の3期に分けて，何が貧酸素水塊の消長に影響を与 えているかについて分析を行う.ここでは貧酸素水塊が 発達し，衰退していく大きな季節変動だけではなく，気 象や水温の違いによって生起される, 発達・衰退過程の 違いに着目して解析を行う.

\section{(1)発達期における影響}

図-4に2002年および2003年の6月〜7月のDOの縦断分 布を示す．絴断分布は図-1に破線で示した測点D1〜 A3 のものである. 図中の黒色の縦棒は西宮防波堤，底層付 近の濃い灰色の領域はDOが3mg/以下の貧酸素水塊を表 している．港内のDOについてみると，2002年は2003年 に比べて，6月中旬にすでに貧酸素化が進んでいること が分かる．2002年においては，6月25日には湧昇が起き， 港奥では青潮が発生し，その後，8月に向けて，貧酸素
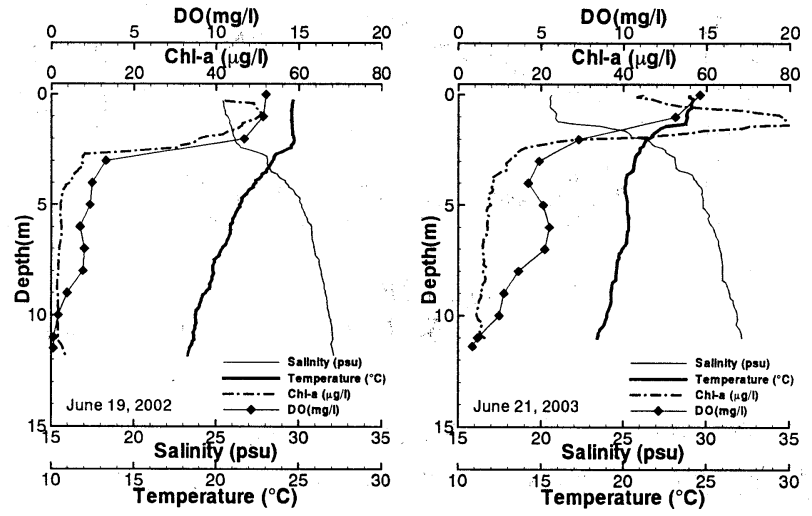

(a) 2002年6月19日

(b) 2003 年 6 月 21 日

国-5 測点B2における塩分・水温・クロロフィルa ・DOの鉿直分布

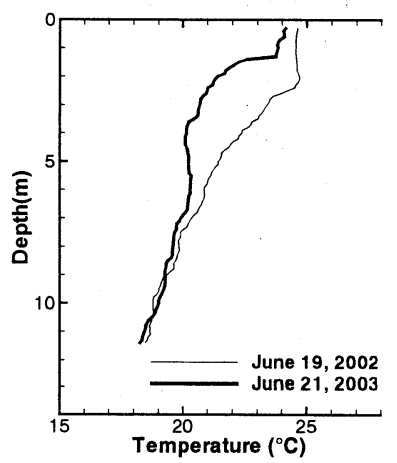

国-6 測点 $\mathrm{B} 2$ における水温の鈶直分布の比較

水塊が発達していく．2003年は，6月には貧酸素化が進 まず，7月になってから貧酸素水塊が発達している，そ の後, 低気圧の通過などの目立った気象擾乱がなかった ために，9月上旬にかけて，図-4に示した2003年7月15日 の縦断分布と同様の状況が維持された.

上記の貧酸素水塊の発達の違いについて，その要因を 考察する．底泥による酸素消費の点からみると，両年と も海底面近くでは，6月上旬には貧酸素化しており， 2003年の観測では4月17日にすでに，港奥の測点A3の底 層でDO2.0mg/となっていた。 このときの同水深の水温 

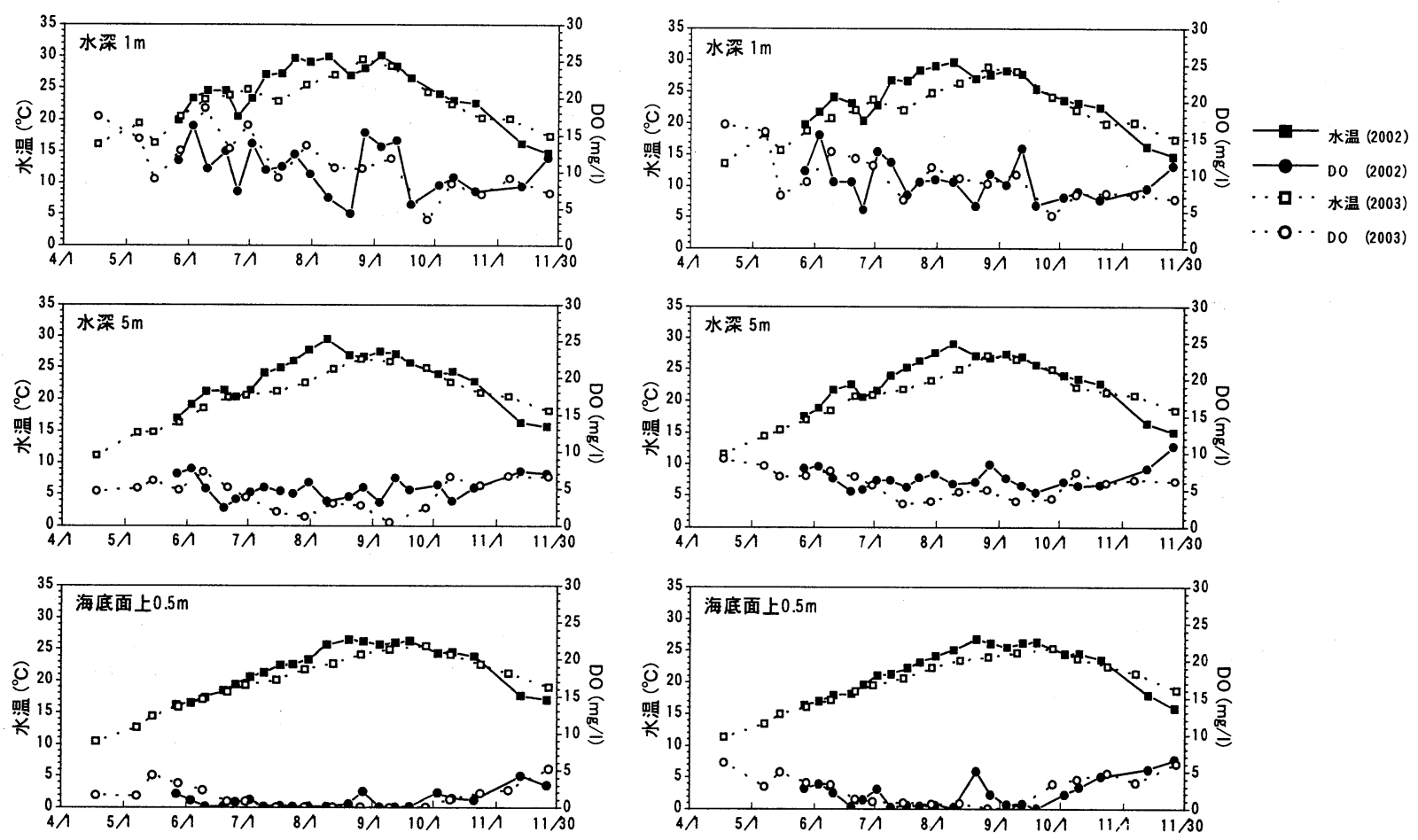

(a) 測点B2

(b)測点D1

口-7 測点B2（港内）およびD1（港外）における水温とDOの季節変化

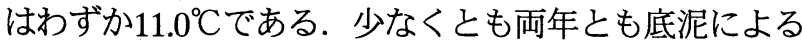
酸素消費は春季から行われているものと考えられる.

図-5に2002年6月19日と2003年6月21日の測点B2の水温, 塩分，DO，クロロフィルa鉛直分布を示す。また, 図-6に両日の水温の鉛直分布を示す。これより，海底面 直上の水温はほぼ同じであることから, 底質に大きな賈 化がなければ，両日の底泥による酸素消費はほぼ同じと も考えられうる.むしろ，両日の大きな違いは水深 $2 \mathrm{~m}$ ～6mの水温である. 2002 年のほうが水温は高く，両日 ひ水温差は, 最も差の大きい水深 $2.4 \mathrm{~m} て ゙ ， 3.5^{\circ} \mathrm{C}$ となつ ている. 中層のDOは2002年の方が低く, 水深 $4 \mathrm{~m} て ゙ D O$ が約 $3 \mathrm{mg} /$ となり，それ以深では貧酸素状態である．ま た，2003年6月21日のDOの鈶直分布を見ると，水深 $1.5 \mathrm{~m}$ の水温・塩分躍層より上層でDOは過飽和状態を示し,

躍層以深では急激に減少し，水深 $4 \mathrm{~m}$ で極小值を示した あと, 水深5 $5 \mathrm{~m}$ でやや大きくなっている. 底層付近でDO は再び小さくなり，DOの鉛直分布は「4層構造」となつ ている.このような4層構造は躍層以深が完全には貧酸 素化しない春季や秋季によく見られ，一連の観測で得ら れた特徵的な結果である. 水温と塩分の鉛直分布をみる と，上層から数えて第2層と第3層間，あるいは第3層と 底層間に大きな密度差は認められないうえに，対象領域 の流速は潮流最大時でも $10 \mathrm{~cm} / \mathrm{s}$ 未満と小さいことから， 第3層のみ違う水塊が貫入している可能性は低い。した がって，第2層の一時的なDO低下は表層からの有機物が 沈降しながら分解される過程で酸素が消費されているも のと考えられる.
以上のように, 水温上昇が夏季の早期から始まると, 中層の貧酸素化が早期に起きやすく，また，同時期の中 層の貧酸素化が表層で生産された有機物の沈降過程で起 きるものと考えうる点から, 貧酸素水塊の発達の違いは 水温上昇とそれに伴う有機物の生産, 有機物による酸素 消費に起因しているものと推察される.

\section{(2)最盛期における影響}

発達期においては, 水温の上昇の違いが貧酸素化の進 展に直接の影響を与えているものと考えられるが，夏季 の最盛期においては, 必ずしもそうではない.ここで最 盛期とは, 気象にも左右されるが, 貧酸素化の状況から, おおむね 7 月中旬 9月中旬を指す．最盛期には，港奥の 人工島背後の水路等では, 底層から密度躍層面までが貧 酸素状態になっている. 図-7に測点B2，D1の水深 $1 \mathrm{~m}$ お よび $5 \mathrm{~m}$, 海底面直上 $0.5 \mathrm{~m}$ の水温とDOの季節変化を示す。 両地点の水深は $11 \mathrm{~m}$ と $15 \mathrm{~m}$ である. 2002年には，6月25日 に低気圧の通過による底層水の涌昇が確認された. その 後, 再び底層水の湧昇が確認される8月20日までは, 全 水深で水温が上昇している．2003年の場合，6月には大 きな気象擾乱がなく，図-3に示すように，7月から8月に かけては2002年に比べて，気温が低く，日照時間も少な い. その影響で, 全水深で水温は上昇しているものの, 2002年に比べて，低く推移している．一方で，水深 $5 \mathrm{~m}$ と底層のDOは水温の低い2003年のほうが小さくなって いる. したがって, 最盛期においては, 水温が高ければ より貧酸素化を進展させる，というわけでは必ずしもな 


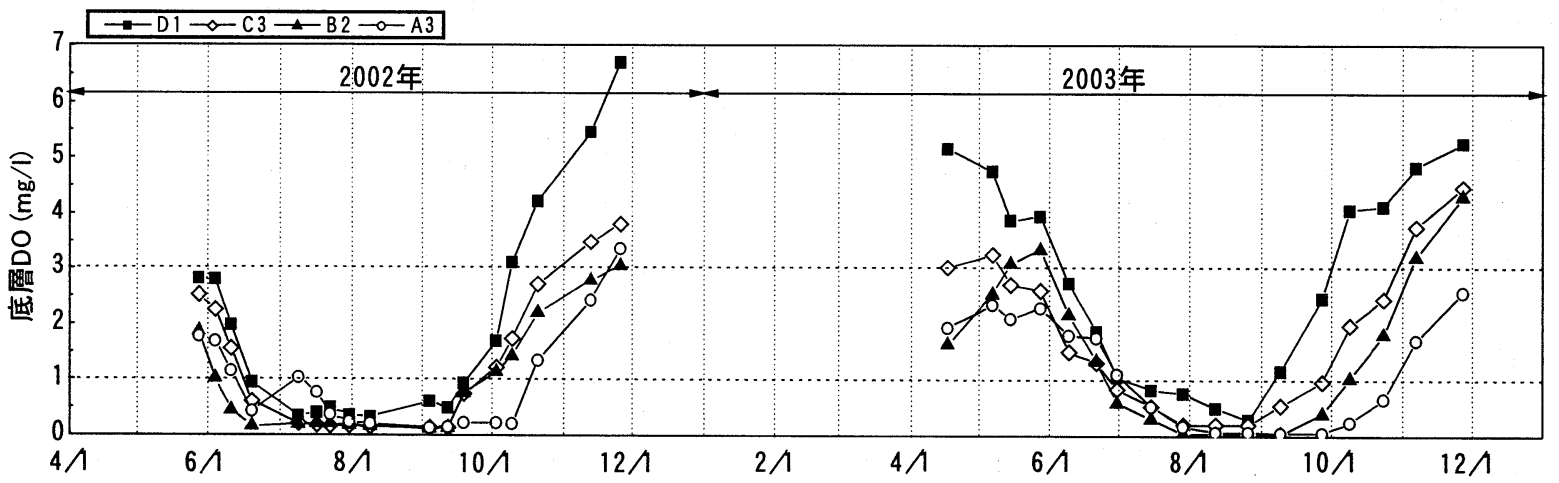

図-8 測点 $\mathrm{A} 3$ （港奥）， B2，C3，D1（港外）の底層のDOの季節変化

い.

この原因として，中層から下層にかけての酸素消費の 主役である有機物が沈降しにくい状態にあることが考え られる. その理由として以下の $2 つ か ゙$ 挙げられる.

a) 夏季に成層が強くなることにより, 鈶直方向の移流が 阻害され，有機物の沈降を妨げている.

b) 上層において, 植物プランクトンの生産に必要な無機 態栄養塩が枯渇するか，あるいは生産に適した水温よ り高くなることによって, 初夏に比べて, 生産量が減 少し, 有機物そのものが減少している.

前報で示したが，夏季の港内の表層においては，無機態 栄養塩はゼロに近く, 表層のクロロフィルaは6月に比べ て, 低くなっている. したがって, 少なくともb)は「最 盛期においては, 高水温が必ずしも貧酸素化を促進させ るわけではない」ことの原因となっているものと考えら れる. 一方，a)については, 確かに2002年のほうが水温 が高く, 成層強度は強くなる, つまり, 沈降速度が遅く なることにより酸素消費が少なくなるが, 成層強度が強 いことによって, どの程度沈降速度が低下しているのか は明らかでなく, 現時点では, 原因であるとは明言でき ない. いずれにせよ, 最盛期においては, 水温上昇が必 ずしも貧酸素化を進展させてはおらず，発達期とは様相 が異なっている.

\section{(3)減退期における影響}

図-8に測点 $\mathrm{A} 3 ， \mathrm{~B} 2 ， \mathrm{C} 3 ， \mathrm{D} 1$ における底層のDOの季節 変化を 2 年連続で示す。ただし, 気象擾乱などによる短 期的な変動を取り除くため, 值は当日と前後各1回のア ンサンブル平均を行っている. 発達期においては, 両年 とも, 全ての測点で同時にDOが低下する. 一方で, 減 退期の底層DOの上昇において，測点間に時期的なずれ が生じている. また，このずれは2003年のほうが顕著で あり, 底層のDOが $2.5 \sim 3 \mathrm{mg} / 1$ 回復するのに, 港奥と港 央の測点間，また，港央と港外の測点間にそれぞれ， 20 〜25日のずれが生じている.

一般的に, 貧酸素状態の衰退は秋季において, 成層崩 壊が起き，鉛直混合が生起されることによると考えられ
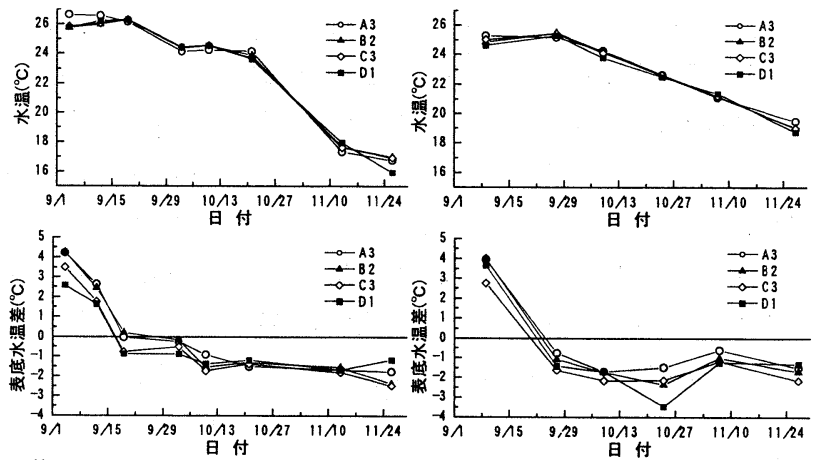

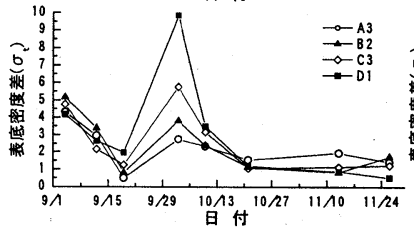

(a) 2002 年

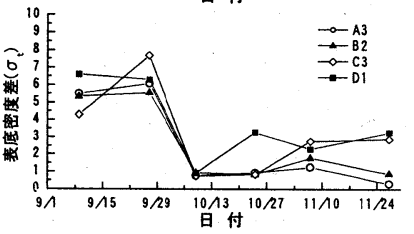

(b) 2003年
-99月以降の底層の水温 - 表底水温差・表底密度差の 時間変化

ている．そこで，2002年および2003年の減退期における 底層の水温. 表底水温差, 表底密度差 (=表層の密度一 底層の密度) の時間変化を図-9に示す，両年とも水温の 時間変化に測点による違いはない，唯一，2002年におい ては11月に入ってから気温が平年より低く推移した影響 で，2003年に比べて，水温が低下していることを示すの みである. 淀川の出水のあった観測日(2002年10月3日)を 除いた表底水温差および表底密度差の傾向は，2002年と 2003年ともよく似ている. 2003年の表底水温差と表底密 度差にはばらつきが見られるが，図-8に示したDOの時 間変化の差異とは一致していない.したがって, 港内外 の貧酸素水塊の衰退の時間的な差は，表底水温差や表底 密度差，つまり，港内の成層の強弱に起因しているとは 考えられない.

貧酸素状態が回復し始め，その回復傾向にばらつきが 見られる9月においては，図-3に示したように，風向が 異なる. 2002年は9月上旬に北風が連吹し，2003年は9月 下旬の台風が通過するまでは夏季の安定的な気象であっ た.このような違いから, 港内外の海水交換機構が異 なっているものと考えられるが，今回のデータからは十 
分な因果関係は認められない.

したがって貧酸素水塊の衰退には, 夏季の最盛期に比 べて成層が弱まることが必要条件ではあるが，一方で, 衰退過程や地点によるその差異は, 各測点における水温 や密度の成層や鉛直構造に起因するのではないものと考 えられる。

\section{4. おわりに}

一連の研究を行うにあたり, 当初から課題となってい たのは，城2が示したような底層DOと表層水温差・表底 密度差の関係，つまり，短期的にせよ長期的にせよ成層 が強まるにつれて, 貧酸素化が進んでいくという, 沿岸 域の貧酸素水塊に見られる一般的な傾向だけでは湾奥閉 鎖性水域の貧酸素水塊の動態や季節変動を説明できない という点にあった，再度，図-5および図-6をみると，表 層と底層の水温はほぼ同じであり, 表底水温差はほぼ同 じである. しかし, 貧酸素水塊の発達状況は大きく異 なっている．城が指摘した「DOの消長は表底水温差と 良く対応する」という点とは異なることが分かる. この ように，湾奥部の閉鎖性水域の貧酸素化は，湾全域の一 般的な消長の傾向とは異なっている.

前々報および前報においては単年での調査における貧 酸素水塊の動態と挙動に及ぼす様々な影響因子について の分析を行った. 本報では, 2ヶ年にわたり詳細な観測 を実施し, 解析した結果, 水温が貧酸素水塊の消長に影 響を及ぼしていることが分かった. しかし，どの時期に おいても水温の上昇が貧酸素水塊の拡大をもたらすわけ ではない. 水温上昇の時期も重要な因子となる.

湾奥閉鎖性水域における貧酸素水塊の季節変動につい て, 以下に結論を示す.

(1) 貧酸素水塊発達期においては, 一般的に水温の上昇 により貧酸素化が進むが, 早期の水温上昇は活発な 植物プランクトン生産とその分解に伴う酸素消費を もたらし，早期に貧酸素水塊が拡大する契機となる. 貧酸素化の進展に年度ごとに差異が生じる原因は中 層における有機物の分解量によるところが大きいと 考えられる.

(2) 貧酸素水塊最盛期においては, 水温上昇が貧酸素水 塊の消長に与える影響は小さい，最盛期においては, 表層の無機態栄養塩が枯渇し, 初夏に比べて植物プ ランクトンの生産が減少しているものと考えられ, そのことも一因となって, 結果として, 水温の違い
による酸素消費量の違いが現れにくくなっているも のと推察される.

(3) 貧酸素水塊衰退期においては, 成層の崩壊が貧酸素 水塊の減少をもたらすが, 解消時期については, 地 点間の差異が認められる. しかし，この差異の原因 は水温や密度の成層の違いによるものではないと考 えられる。

(4) 沿岸域の一般的な貧酸素水塊の消長と湾奥部閉鎖性 水域の貧酸素水塊の消長が一致した傾向を見せない のは，成層強度が強くなるにつれ貧酸素化するとい う特性を共通点として持ちながら，一方で，港内外 の海水交換機構の違いなどに加えて, 閉鎖性水域内 の中層における酸素消費の影響が，一般的な沿岸域 よりも大きいことも原因であると推察される.

これまで，下層での酸素消費過程が十分に明らかでな かったため, 有機態分解による酸素消費と底泥による酸 素消費を分けて考えることが十分にはできなかった．本 報では，閉鎖性水域においては中首における酸素消費も 貧酸素水塊の発達・消滅過程に重要な役割を果たしてい ることを明らかにした. 今後はこの点を実証すべく，中 層で有機物が分解されるときの酸素消費量とその過程が 貧酸素水塊の消長に及ぼす影響について，さらに定量的 な評価が望まれる。

謝辞 : 本研究は科学研究費補助金 - 基盤研究(A)(2)（課 題番号14205073，代表者中辻啓二）により行われ，国土 交通省近畿地方整備局神戸港湾空港技術調查事務所と大 阪大学との協力による「大阪湾湾奥部閉鎖性海域貧酸素 水塊調査」によるものであることを付記し，ここに深甚 の謝意を表する.

\section{参考文献}

1) 中辻啓二, 入江政安, 西田修三, 湯浅楠勝 : 大阪湾湾奥部 閉鎖性海域における貧酸素水塊の現地調查, 水工学論文集, 第47巻, pp.1285-1290, 2003.

2) 城久: 大阪湾の貧酸素水塊, 沿岸海洋研究ノート, 第26巻 第2号, pp.87-97, 1989.

3) 入江政安・西田修三・中辻啓二・金俊憲・湯浅楠勝 : 都市 域近傍の閉鎖性水域の貧酸素水塊の挙動に及ぼす気象の影響, 海岸工学論文集, 第50巻, pp.991-995, 2003

(2004.9. 30 受付) 